\title{
Review
}

\section{Pathogenesis of Type 2 (non-insulin-dependent) diabetes mellitus: candidates for a signal transmitter defect causing insulin resistance of the skeletal muscle}

\author{
H. U.Häring and H. Mehnert \\ Institute for Diabetes Research and III Medical Department, Krankenhaus München-Schwabing, München, Germany
}

\begin{abstract}
Summary. Insulin resistance of skeletal muscle, liver and fat combined with an abnormality of insulin secretion characterizes Type 2 (non-insulin-dependent) diabetes mellitus. There is increasing evidence that the insulin resistance of the skeletal muscle plays a key role early in the development of Type 2 diabetes. As a consequence recent research efforts have focussed on the characterization of insulin signal transduction elements in the muscle which are candidates for a localization of a defect causing insulin resistance i. e. the insulin receptor, phosphatases related to insulin action, glycogen synthase and the glucose transporters. In this review we at-
\end{abstract}

tempt to summarize present knowledge about abnormalities of these systems in skeletal muscle of Type 2 diabetic and pre-diabetic individuals. We try to classify abnormalities as secondary events or as candidates for putative primary molecular defects which might initiate the development of insulin resistance as early as in the "pre-diabetic" state.

Key words: Type 2 (non-insulin-dependent) diabetes mellitus, insulin resistance, insulin receptor, phosphatases, glycogen synthase, glucose transporter.
Clinically overt Type 2 (non-insulin-dependent) diabetes mellitus is characterized by insulin resistance of all major target tissues, i. e. skeletal muscle, liver and fat combined with an abnormality of insulin secretion [1]. Several studies in recent years have shown that the clinical onset of Type 2 diabetes in different high-risk populations is preceded by an undefined time period when insulin resistance may be detected [2-7]. The clinical features of the potential pre-diabetic state in high-risk groups include insulin resistance, increased abdominal fat, elevated very low density lipoproteins and decreased high density lipoproteins, as well as elevated fasting and postprandial insulin levels [2-7]. Furthermore, in some populations hypertension is associated [8-11] with this clinical syndrome which was recently named syndrome-X. It is also known as metabolic endocrine syndrome, hyperinsulinaemia-insulin resistance syndrome and what we had earlier designated [12] "Wohlstandssyndrom" ("affluence or post-war syndrome").

As recently reviewed [13] a variety of different mechanisms which cause insulin resistance at different levels of the insulin signal transducing chain and at different target cells have been described in Type 2 diabetes. There is sufficient evidence to assume that insulin resistance found in Type 2 diabetes is the result of several different pathogenic mechanisms (Fig. 1). Most of these mechanisms might be the consequence of metabolic derangements such as hyperglycaemia, elevated non-esterified fatty acids or alterations of the insulin level placing them in the category of secondary events in the development of the disease. On the other hand, the recently available data on the pre-diabetic populations have clearly shown that insulin resistance of the skeletal muscle is a very early event in the development of the disease which exists before metabolic derangements occur [2, 3, 14-19]. This strongly suggests the existence of a primary molecular defect of insulin action in the skeletal muscle. This putative primary defect might initiate a sequence of events leading to the secondary insulin resistance mechanisms which then in concert with the postulated primary defect cause the variable levels of insulin resistance which are observed in the different clinical stages of Type 2 diabetes (Fig. 1). Most of the data available on abnormalities of insulin signalling and action in Type 2 diabetes were obtained in late stages of the development of the disease. Only recently an increasing amount of information about the functional status of signal transduction elements in the skeletal muscle of prediabetic individuals has become available. In this review we attempt to give an update of the published data concerning the signal transduction elements which have been most extensively studied in recent years, $\dot{i}$. e the insulin receptor kinase, the phosphatases related to insulin action, glucose transporters and the glycogen synthase. We will also focus on whether abnormalities found in 


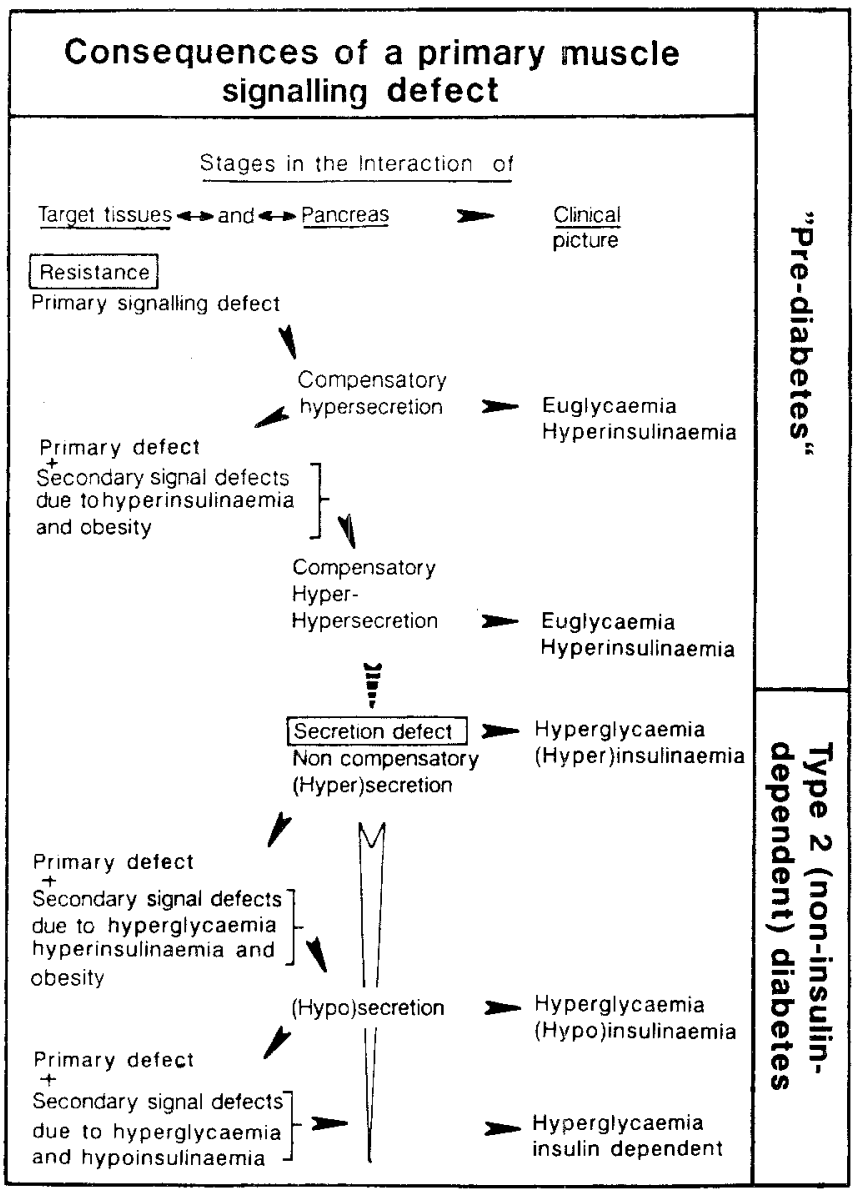

Fig.1. Stages in the development of Type 2 diabetes. The development of pre-diabetes and Type 2 diabetes could be initiated by a primary insulin signalling defect located in the skeletal muscle. Compensatory hyperinsulinaemia may cause secondary events increasing target tissue resistance

these systems may be candidates for the primary molecular defect initiating the pathogenesis of Type 2 diabetes. Criteria classifying these abnormalities are provided by data which concern reversibility of the "defects" and data which indicate a specific abnormality already seen in prediabetic populations. Furthermore, ongoing studies which are screening for mutations of the genes encoding these cellular signal transduction elements may provide evidence as to whether these abnormalities should be regarded as secondary or primary events.

\section{The insulin receptor}

The insulin receptor as the first element of cellular signal transduction is a strong candidate for the location of a defect in insulin signalling. A number of studies have shown that in syndromes of severe insulin resistance a number of different point mutations of the insulin receptor gene exist [20]. Some of these point mutations were functionally relevant and caused different forms of receptor defects with consequences for insulin binding characteristics, consequences for the signalling capacity of the tyrosine kinase of the insulin receptor or other abnormalities [20]. While in forms of extreme insulin resistance, structural and func- tional defects at the receptor level have been clearly described, the situation in common Type 2 diabetes is less clear. The insulin receptor has been functionally characterized in all major target tissues - skeletal muscle, liver and fat [21-29]. In liver and skeletal muscle all data were obtained exclusively on isolated receptors after in vitro or in vivo stimulation $[21-24,29]$. It is not known how these receptors behave in their natural cell environment. Only in fat cells from Type 2 diabetic patients are there data from intact cells $[25,26,28]$ in addition to the information on isolated receptors. Binding capacity and affinity is generally found to be unaltered for the skeletal muscle $[21-23,27]$, and liver [24] while it was found to be decreased in fat [25]. Activation of the insulin receptor kinase was found to be decreased in receptors from all these tissues. In general, an approximate $50 \%$ decrease of the insulin response and an insensitivity towards low insulin concentrations were found.

\section{Mechanisms of reduced insulin receptor kinase activity}

Analysis of the defective mechanism on the protein level has revealed two interesting observations. For the insulin receptor kinase in fat it was shown that the total receptor population exists in active and inactive forms [28]. In Type 2 diabetes it appeared that the inactive form was increased [28]. In kinase isolated from skeletal muscle an altered autoactivation cascade was found suggesting that the partial inactivity might be a consequence of an incomplete autoactivation process [27]. The reason for the altered activation process is unknown.

For the kinase defect in fat a partial reversibility was demonstrated pointing towards a secondary mechanism at least in this tissue [26]. Analogous observations for muscle and liver are not available. Several studies have been performed which have investigated whether in analogy to the syndromes of severe insulin resistance a mutation of the insulin receptor gene causes the inactivity of the insulin receptor kinase. In the majority of cases relevant mutations of the insulin receptor gene have not been detected [30-34]. Using screening techniques such as denaturing gradient gel electrophoresis (DGGE) or singlestranded-conformation-polymorphism (SSCP) analysis more than 100 Type 2 diabetic patients were studied by different investigators [30-34]. Mutations were identified in only a few patients [33] and in most of these patients there is no proof that these mutations cause a reduced signalling capacity of the receptor. Taken together these results argue against a primary, genetically determined defect of the receptor and point rather to a regulatory, possibly secondary mechanism causing kinase inactivity in skeletal muscle from Type 2 diabetic patients. As reviewed recently [13] a number of mechanisms are known which can inhibit the activity of the insulin receptor kinase such as increased serine phosphorylation of the receptor, modulation by inhibitors such as G-proteins and inhibitory peptides, glucose induced inhibition through activation of protein kinase $\mathrm{C}$ or inhibition through chronic hyperinsulinaemia. There are interesting reports that peptide inhibitors of the receptor kinase are increased in fibroblasts of insulin resistant Type 2 diabetic patients [ 35 , 
36]. However, though potentially important, none of the above-mentioned mechanisms has proven to be relevant for Type 2 diabetic skeletal muscle.

\section{Insulin receptor kinase activity in pre-diabetes}

Independent of the underlying mechanism the question remains whether the kinase inactivity is an early event in the pathogenesis or whether it contributes later in the development of the disease, by increasing skeletal muscle insulin resistance in an additive way to the putative primary defect. Up to now two studies have addressed this question. One report on pre-diabetic Pima Indians showed that the tyrosine kinase of the skeletal muscle is normal in this population [37]. In contrast decreased basal and insulin-stimulated insulin receptor kinase activity were recently observed in a Danish pre-diabetic population [38] and thus the authors suggest that kinase inactivity is a candidate for the primary defect.

In summary, while there is sufficient evidence to conclude that insulin receptor kinase inactivity contributes to the insulin resistant state of the skeletal muscle in later stages of Type 2 diabetes, questions remain unanswered as to the underlying mechanism of kinase inactivity and to the status of the primary or secondary event.

\section{Insulin receptor isoform pattern}

Another aspect of the insulin receptor has recently attracted interest. As a consequence of tissue specific alternative splicing of mRNA of the proreceptor, the human insulin receptor (HIR) exists in two isoforms tentatively named HIR-A and HIR-B [39-41]. Most of the functional properties of the two receptor isoforms are identical [4248] while some characteristics such as binding affinity [39, 42] internalization, recycling [48] and down-regulation appear to be different. However, at present specific differences in biological functions of the two isoforms are not understood. When the tissue specific expression of the isoforms in Type 2 diabetes and severe insulin resistance were investigated, conflicting results were reported. While we $[49,50]$ and others $[51,52]$ found evidence at both the protein and mRNA level for an altered isoform pattern, this finding was not confirmed by other investigators $[53,54]$. The reason for the discordant results is unclear. Even though the biological significance of an altered insulin receptor isoform expression cannot be interpreted at present, it is interesting to note that in a prediabetic population the altered expression of receptor isoforms in the skeletal muscle was associated with skeletal muscle insulin resistance [55]. This suggests that an altered splicing of mRNA for the proreceptor is one of the candidates for very early molecular defects in the development of skeletal muscle insulin resistance.

\section{Post-kinase signal transducers}

The mechanism of insulin signal transduction at the postkinase level is still not well understood [13]. As a consequence no data are available concerning defects in the post-kinase signal transmitting systems in Type 2 diabetic skeletal muscle. Phospholipase $\mathrm{C}$ activity, which might play a role in insulin signalling, has been reported to be increased in the liver of Type 2 diabetic patients [56]. A putative second messenger of insulin action, which might be released from the plasma membrane by phospholipase $\mathrm{C}$ activation, chiroinositol, is reduced in pre-diabetic Pima Indians [57]. The significance of these observations is not yet clear.

\section{Phosphatases}

Phosphatases are interesting candidates for a molecular defect causing insulin resistance as they modulate insulin signal transduction at different levels of the signal transmitting chain [13]. Tyrosine specific phosphatases in the cell are involved in the regulation of the autophosphorylation status of the insulin receptor controlling its signalling activity. Since at the post-kinase level tyrosine phosphorylation of substrate proteins may be involved in insulin signalling, an analogous role of tyrosine phosphatases for the regulation of post-kinase signalling mechanisms has to be assumed. Furthermore, it is believed that the insulin signal transmission mechanism switches at some point in the signalling chain from tyrosine phosphorylation to serine phosphorylation. At this level of signal transduction serine phosphatases play an important role.

Tyrosine phosphatase (P'TPase) activity was studied in skeletal muscle of insulin-resistant Pima Indians [58]. In this study increased basal PTPase and insufficient insulin suppression of PTPase activity were found in resistant individuals. In another study in Type 2 diabetic patients, where PTPase activity against an insulin-receptor-like substrate was measured, a decreased PTPase activity was found in insulin-resistant skeletal muscle [59]. Thus, the significance of altered PTPase activity in the pathogenesis of skeletal muscle insulin resistance remains unknown.

Recently, interesting data concerning serine phosphatases were reported. Of major interest is how serine phosphatases control the activity of the enzyme glycogen synthase. A decreased basal and insulin-stimulated glycogen phosphatase activity and phosphorylase phosphatase activity (type-1 protein phosphatase, PP-1) in the skeletal muscle of insulin resistant individuals has been found [16, 19,60]. Furthermore the effect of insulin on the gene expression of PP-1 is different between sensitive and resistant skeletal muscle [61]. These observations might be important for the understanding of the altered effects of insulin on glycogen synthase. It is important to note that these abnormalities of PP-1 are observed even in the prediabetic state.

\section{Glycogen synthase}

While in Type 2 diabetes both oxidative and non-oxidative glucose disposal in the skeletal muscle are impaired [1], only non-oxidative glucose disposal appears to be reduced in the pre-diabetic state $[2,3]$. This observation indicates a pivotal role for glycogen synthase. The effect of 
insulin on skeletal muscle glycogen synthase both in Type 2 diabetic patients as well as in pre-diabetic subjects has been well studied [1, 3, 14-16, 62-64]. Glycogen synthase activity is regulated by phosphorylation and dephosphorylation. A number of serine specific kinases phosphorylate glycogen synthase at different residues [65], and at least two phosphatases regulate the dephosphorylation [65]. Dephosphorylation converts the enzyme from a glucose 6-phosphate dependent form to a glucose 6-phosphate independent form. Insulin activates the enzyme by activating glycogen synthase phosphatase and inhibiting one of the glycogen synthase kinases, cAMP-dependent kinase [66]. The inhibition of CAMP-dependent kinase appears to lower the phosphorylation of glycogen synthase phosphatase-inhibitor-I leading to activation of glycogen synthase phosphatase [66]. It is generally found that the insulin effect on glycogen synthase from skeletal muscle of Type 2 diabetic patients is reduced [62-64]. Recently, it was shown by nuclear magnetic resonance technology that the decreased effect of insulin on the enzyme is relevant in vivo leading to a decreased rate of glycogen synthesis [67]. The mechanism of reduced glycogen synthase activity is not clear. It has been reported that the activation of the dependent enzyme form by glucose 6-phosphate is normal [62] suggesting that no defect of the enzyme itself exists. A recent study in skeletal muscle of Type 2 diabetic patients suggests that relevant mutations of glycogen synthase or the catalytic subunit of the glycogen synthase related protein phosphatase I are obviously not the cause of the reduced activity [68].

\section{Glycogen synthase activity in pre-diabetes}

An abnormality of glycogen synthase activation is likely to be a very early event in the development of Type 2 diabetes as this abnormality has been reported in the prediabetic state $[14-16,69]$. The level of expression of the glycogen synthase protein in skeletal muscle in prediabetic individuals and Type 2 diabetic patients after insulin stimulation is not decreased. On the contrary it seems to be somewhat increased which might reflect a compensatory mechanism [69]. In summary, concerning the underlying mechanism, the above-mentioned data suggest that glycogen synthase itself is not defective. It appears rather that some step in the signal transduction between the insulin receptor and glycogen synthase, possibly at the level of signal transduction to the phosphatases, may be altered. However, the observation that in all prediabetic populations the abnormality of glycogen synthase and related phosphatases is already present makes this system a strong candidate for the initiating event of muscle resistance.

\section{Glucose transporter}

Nuclear magnetic resonance studies suggest that in Type 2 diabetic muscle the transport of glucose is decreased [70]. The molecular mechanism is unclear. No analogous data have been reported for the pre-diabetic state. The glucose transporter consists of a family of isoforms with different tissue specific expression named GLUT 1-5 [71]. The effect of insulin on glucose transport involves a translocation of glucose transporters from intracellular membranes to the plasma membrane [72], but the second step probably involves the activation of transporters in the plasma membrane [73]. The question of whether an abnormality of the glucose transport system contributes to the insulin resistance in Type 2 diabetes was first addressed in adipocytes from Type 2 diabetic patients. In these studies both a decreased expression of the relevant glucose transporter isoform GLUT 4 as well as a decreased translocation and activation of glucose carriers to the plasma membrane was found [74]. A number of studies have since addressed the question of whether alterations of GLUT 4 expression can be detected at the level of the skeletal muscle. The majority of the data suggest that the expression of GLUT 4 in skeletal muscle is not significantly decreased. The functional properties of the glucose transporters are not known as no studies on translocation or activation of GLUT 4 from Type 2 diabetic skeletal muscle have been published. In skeletal muscle biopsies from musculus vastus lateralis, normal expression of GLUT 4 both at the mRNA and protein level was described $[75,76]$. Other data obtained in musculus rectus abdominis suggested a decreased level of GLUT 4 [77] which is in agreement with our own studies in musculus gastrocnemius [78]. On the other hand this group showed in an elegant study in musculus rectus abdominis from insulin-resistant patients that the state of insulin resistance does not correlate with the total level of GLUT 4 protein [79]. It will be important to know whether GLUT 4 levels in plasma membranes and transverse tubules after insulin stimulation are altered. At least in the basal state we observed an altered subcellular distribution of GLUT 4 in gastrocnemius muscle [78]. The discrepancies among the results might be the consequence of the different muscle types which were studied or more likely a consequence of different patient characteristics. In our study patients were clearly older and had a longer duration of Type 2 diabetes than in the other studies where no abnormality could be detected. This suggests that an alteration of GLUT 4 expression might be a very late phenomenon in the development of skeletal muscle insulin resistance and may not be considered as a primary defect. This conclusion is in agreement with a recent report where in pre-diabetes no altered expression of GLUT 4 could be detected [80]. Furthermore no mutation of the glucose transporter gene could be detected in Type 2 diabetic patients $[32,81]$. These data do not exclude that an abnormality of GLUT 4 activation or translocation might occur at an earlier stage of the pathogenesis of Type 2 diabetes, as published studies have not addressed this important question.

\section{Speculation on the primary defect}

Available data suggest that neither the normal function of the insulin receptor kinase nor the glucose transporter GLUT 4 nor glycogen synthase itself are altered due to a mutation in these proteins. The reduced insulin stimulated activity of the insulin receptor and the glycogen syn- 


\begin{tabular}{|c|c|}
\hline \multicolumn{2}{|c|}{$\begin{array}{c}\text { Abnormalities of signal transduction in the skeletal muscle } \\
\text { in Type } 2 \text { diabetes }\end{array}$} \\
\hline in "Pre-diabetes"
\end{tabular}

Fig. 2. Synopsis of published data on abnormalities of signal transduction in the skeletal muscle in clinically overt Type 2 diabetes and in pre-diabetes. The figure shows the chain of signal transducing events at the target cells. The sites of defects in the signal flow are marked in bold letters thase both seem to be a consequence of altered regulatory mechanisms. Whether the intrinsic activity or the translocation of GLUT 4 is altered is unknown. Studies in prediabetic populations have uniformly shown that the impaired glycogen synthase activity is a very early event in the development of Type 2 diabetes while the data concerning the insulin receptor kinase inactivity are controversial. Other early events might be altered receptor isoform patterns and altered functions of PP-1. Thus the synopsis of the available data (Fig.2) does not allow the initiating event in the development of skeletal muscle resistance to be defined. Hopefully a better understanding of the post-kinase signal transmitting steps will allow future progress in this field. Recently, the first putative substrate of the insulin receptor kinase (IRS1) was cloned [82]. This will allow the question of whether the expression level of this substrate or its functional properties are altered in Type 2 diabetic patients and pre-diabetic populations to be specifically addressed.

Acknowledgements. We thank M.Kellerer, B.Obermeier and L. Mosthaf for critical reading of the manuscript. H. Häring, M. Kellerer, B. Obermeier and L. Mosthaf congratulate H. Mehnert on his $65^{\text {th }}$ birthday on 26 February 1993.

\section{References}

1. DeFronzo RA, Bonadonna RC, Ferrannini E (1992) Pathogenesis of NIDDM: a balanced overview. Diabetes Care 15:318-368

2. Eriksson J, Franssila-Kallunki A, Ekstrand A et al. (1989) Early metabolic defects in persons at increased risk for non-insulin-dependent diabetes mellitus. N Engl J Med 321: 337-343

3. Warram JH, Martin BH, Krolewski AS, Soeldner JS, Kahn CR (1990) Slow glucose removal rate and hyperinsulinemia precede the development of type II diabetes in the offspring of diabetic patients. Ann Intern Med 113:909-915

4. Lillioja S, Mott DM, Howard BV et al. (1988) Impaired glucose tolerance as a disorder of insulin action. Longitudinal and crosssectional studies in Pima Indians. N Engl J Med 318: 1217-1225

5. Haffner SM, Stern MP, Hazuda HP, Pugh JA, Patterson JK (1986) Hyperinsulinemia in a population at high risk for non insulin dependent diabetes mellitus. N Engl J Med 315: 220-224
6. Bergstrom RW, Newell-Morris L, Leonetti DL, Shuman WP, Wahl PW, Fujimoto WY (1990) Association of elevated fasting C-peptide level and increased intra-abdominal fat distribution with development of NIDDM in Japanese-American men. Diabetes 39: 104-111

7. Sicree RA, Zimmet PZ, King HOM, Coventry IS (1987) Plasma insulin response among Nauruans: prediction of deterioration in glucose tolerance over 6 years. Diabetes 36: 179-186

8. Modan M, Halkin H, Almog S et al. (1985) Hyperinsulinemia: a link between hypertension, obesity and glucose intolerance. $J$ Clin Invest 75: 809-817

9. Ferrannini E, Buzzigoli G, Bonadonna R et al. (1987) Insulinresistance in essential hypertension. N Engl J Med 317: $350-357$

10. Fournier AM, Gadia MT, Kurulsy DB, Skyler JS, Sosenko JM (1986) Blood pressure, insulin, and glycemia in non-diabetic subjects. Am J Med 80: 861-864

11. Dieterle P, Fehm H, Ströder W, Henner J, Bottermann P, Schwarz K (1967) Asymptomatischer Diabetes mellitus bei normalgewichtigen Hypertonikern. Dtsch Med Wschr 92: 2376

12. Mehnert H, Kuhlmann H (1968) Hypertonie und Diabetes mellitus. Deutsches Medizinisches Journal 19. Jahrgang, Heft 16

13. Häring HU (1991) The insulin receptor: signalling mechanism and contribution to the pathogenesis of insulin resistance. Diabetologia 34: 848-861

14. Vaag A, Henriksen JE, Beck-Nielsen H (1992) Decreased insulin activation of glycogen synthase in skeletal muscles in young nonobese caucasian first-degree relatives of patients with non-insulin-dependent diabetes mellitus. J Clin Invest 89: 782-788

15. Schalin-Jäntti C, Härkönen M, Groop LC (1992) Impaired activation of glycogen synthase in people at increased risk for developing NIDDM. Diabetes 41: 598-604

16. Kida Y, Esposito-Del Puente A, Bogardus C, Mott DM (1990) Insulin resistance is associated with reduced fasting and insulinstimulated glycogen synthase phosphatase activity in human skeletal muscle. J Clin Invest 85: 476-481

17. Kida Y, Nyomba BL, Bogardus C, Mott DM (1991) Defective insulin response of cyclic adenosine monophosphate-dependent protein kinase in insulin resistant humans. $J$ Clin Invest 87: 673 679

18. Katz A, Bogardus C (1990) Insulin-mediated increase in glucose 1,6-biphosphate is attenuated in skeletal muscle of insulin-resistant man. Metabolism 39: 1300-1304

19. Kida Y, Raz I, Maeda R et al. (1992) Defective insulin response of phosphorylase phosphatase in insulin-resistant humans. J Clin Invest 89: 610-617

20. Taylor SI, Kadowaki T, Kadowaki H, Accili D, Cama A, McKeon C (1990) Mutations in the insulin receptor gene in insulin resistant patients. Diabetes Care 13: 257-279 
21. Arner P, Pollare T, Lithell H, Livingston JN (1987) Defective insulin receptor tyrosine kinase in human skeletal muscle in obesity and type 2 (non-insulin-dependent) diabetes mellitus. Diabetologia 30: $437-440$

22. Häring HU, Obermaier B, Ermel B et al. (1987) Insulin receptor kinase defects as a possible cause of cellular insulin resistance. Diabete Metab 13: 284-293

23. Caro JF, Ittoop O, Poreis WJ et al. (1987) Insulin receptor kinase in human skeletal muscle from obese subjects with and without non-insulin-dependent diabetes mellitus. J Clin Invest 82: 13981406

24. Caro JF, Ittoop O, Poreis WJ et al. (1986) Studies on the mechanism of insulin resistance in the liver from humans with noninsulin-dependent diabetes mellitus. J Clin Invest 78: 249-258

25. Freidenberg GR, Henry RR, Klein HH, Olefsky JM (1987) Decreased kinase activity of insulin receptors from adipocytes of non-insulin-dependent diabetic subjects. J Clin Invest 79: 240-250

26. Freidenberg GR, Reichart D, Olefsky JM, Henry RR (1988) Reversibility of defective adipocyte insulin receptor kinase activity in non-insulin-dependent diabetes mellitus. J Clin Invest 82: $1398-1406$

27. Obermaier-Kusser B, White MF, Pongratz DE etal. (1989) A defective intramolecular autoactivation cascade may cause the reduced kinase activity of the skeletal muscle insulin receptor from patients with non-insulin-dependent diabetes mellitus. J Biol Chem 264: 9497-9503

28. Brillon DJ, Freidenberg GR, Henry RR, Olefsky JM (1989) Mechanism of defective insulin-receptor kinase activity in NIDDM. Evidence for two receptor populations. Diabetes 38: 397-403

29. Nolan JJ, Reichart D, Freidenberg G, Henry RR (1992) Role of skeletal muscle insulin receptor kinase in in vivo insulin resistance in NIDDM and obesity. Diabetes 41 [Suppl]: $184 \mathrm{~A} \mathrm{(Ab-}$ stract)

30. Moller DE, Yokota A, Flier JS (1989) Normal insulin receptor cDNA sequence in Pima Indians with NIDDM. Diabetes 38: $1496-1500$

31. O'Rahilly S, Choi WH, Patel P, Turner RC, Flier JS, Moller DE (1991) Detection of mutations in insulin-receptor gene in NIDDM patients by analysis of single-stranded conformation polymorphisms. Diabetes 40: 777-782

32. Kusari J, Verma US, Buse JB, Henry RR, Olefsky JM (1991) Analysis of the gene sequences of the insulin receptor and the insulin-sensitive glucose transporter (GLUT-4) in patients with common-type non-insulin-dependent diabetes mellitus. J Clin Invest 88: 1323-1330

33. Cocozza S, Porcellini A, Riccardi G et al. (1992) NIDDM associated with mutation in tyrosine kinase domain of insulin receptor gene. Diabetes 41: 521-526

34. Formisano P, Riccardi G, Miele C et al. (1992) Functional properties of an insulin receptor mutation occurring in NIDDM. Diabetes 41 [Suppl]: 70 A (Abstract)

35. Sbraccia P, Goodman PA, Maddux BA et al. (1991) Production of inhibitor of insulin-receptor tyrosine kinase in fibroblasts from patient with insulin resistance and NIDDM. Diabetes 40:295-299

36. Maddux BA, Sbraccia P, Chen I, Hollenbeck C, Goldfine ID (1992) Inhibitors of insulin receptor tyrosine kinase in fibroblasts from native Americans with NIDDM. Diabetes 41 [Suppl]: $108 \mathrm{~A}$ (Abstract)

37. Bulangu LN, Ossowski VM, Bogardus C, Mott D (1990) Insulinsensitive tyrosine kinase: relationship with in vivo insulin action in humans. Am J Physiol 258: E 964-E 974

38. Handberg A, Vaag A, Vinten J, Beck-Nielsen H (1992) Defect insulin receptor kinase in muscle from young relatives of type 2 diabetic patients. Diabetes 41 [Suppl]: $63 \mathrm{~A}$ (Abstract)

39. Mosthaf L, Grako K, Dull TJ, Coussens L, Ullrich A, McClain DA (1990) Functionally distinct insulin receptors generated by tissue-specific alternative splicing. EMBO J 9:2409-2414

40. Moller DE, Yokota A, Caro JF, Flier JS (1989) Tissue-specific expression of two alternatively spliced insulin receptor mRNAs in man. Mol Endocrinol 3: 1263-1269
41. Seino S, Bell GI (1989) Alternative splicing of human insulin receptor messenger RNA. Biochem Biophys Res Comm 159: 312 316

42. Kellerer M, Lammers R, Ermel B, Ullrich A, Häring HU (1992) Distinct $\alpha$-subunit structures of human insulin receptor $A$ and Bvariants determine differences in tyrosine kinase activities. Biochemistry 31: 4588-4596

43. Carrascosa JM, Vogt B, Ullrich A, Häring HU (1991) Activation of phosphatidylinositol-3-kinase by insulin is mediated by both $A$ and $B$ human insulin receptor types. Biochem Biophys Res Commun 174: 123-127

44. Kellerer M, Machicao F, Seffer E, Mushack J, Ullrich A, Häring $\mathrm{HU}$ (1991) Stimulation of phospholipase C activity by insulin is mediated by both isotypes of the human insulin receptor. Biochem Biophys Res Commun 181: 566

45. Müller HK, Seidl G, Ullrich A, Häring HU (1991) Both insulin receptor isoforms (HIR-A, HIR-B) are able to induce the synthesis of glucose carrier m-RNA in rat 1-fibroblasts. Diabetologia 34 [Suppl]: A26 (Abstract)

46. Yamaguchi Y, Flier JS, Yokota A, Benecke H, Backer JM, Moller DE (1991) Functional properties of two naturally occurring isoforms of the human insulin receptor in Chinese hamster ovary cells. Endocrinology 129:2058

47. McClain DA (1991) Different ligand affinities of the human insulin receptor splice variants are reflected in parallel changes in sensitivity for insulin action. Mol Endocrinol 5: 734-739

48. Vogt B, Carrascosa JM, Ermel B, Ullrich A, Häring HU (1991) The two isotypes of the human insulin receptors (HIR-A and HIR-B) follow different internalization kinetics. Biochem Biophys Res Commun 177: 1013-1018

49. Mosthaf L, Vogt B, Häring HU, Ullrich A (1991) Altered expression of insulin receptor types $A$ and $B$ in the skeletal muscle of non-insulin-dependent diabetes mellitus patients. Proc Natl Acad Sci USA 88: 4728-4730

50. Kellerer M, Sesti G, Seffer E, Ullrich A, Häring HU (1992) Insulin receptor isoform expression in skeletal muscle membranes of NIDDM patients. Diabetologia 35 [Suppl 1]: A 75 (Abstract)

51. Sesti G, Marini MA, Tullio AN et al. (1991) Altered expression of the two naturally occurring human insulin receptor variants in isolated adipocytes of non-insulin-dependent diabetes mellitus patients. Biochem Biophys Res Commun 181: 1419-1424

52. Van der Vorm ER, Kuipers A, Krans HMJ, Möller W, Maassen JA (1992) A change in alternative splicing of the insulin receptor gene may contribute to severe insulin resistance in leprechaunism. Diabetes 41 [Suppl]: 54A (Abstract)

53. Benecke H, Flier JS, Moller DE (1992) Alternatively spliced variants of the insulin receptor protein. Expression in normal and diabetic human tissues. J Clin Invest 89: 2066-2070

54. Hansen T, Bjøerbeak C, Vestergaard H, Bak JF, Pedersen O (1992) Alternatively spliced variants of the insulin receptor and its functional correlates in muscle from patients with type 2 diabetes and normal subjects. Diabetologia 35 [Suppl 1]: A 76 (Abstract)

55. Mosthaf L, Eriksson J, Häring HU, Groop L, Widen E, Ullrich A (1992) Insulin receptor isotype expression correlates with risk of non-insulin-dependent diabetes. Diabetologia 35 [Suppl 1]: A 75 (Abstract)

56. Thakker JK, DiMarchi R, MacDonald K, Caro JF (1989) Effect of insulin and insulin-like growth factors I and II on phosphatidylinositol and phosphatidylinositol 4,5-biphosphate breakdown in liver from humans with and without type II diabetes. J Biol Chem 264:7169-7175

57. Kennington AS, Hill CR, Craig J et al. (1990) Low urinary chiroinositol excretion in non-insulin-dependent diabetes mellitus. N Engl J Med 323: 373-378

58. McGuire MC, Fields RM, Nyomba BL et al. (1991) Abnormal regulation of protein tyrosine phosphatase activities in skeletal muscle of insulin-resistant humans. Diabetes 40: 939-942

59. Kusari J, Kenner K, Suh KI, Henry RR (1992) Impaired tyrosine phosphatase activity in non-insulin dependent diabetes mellitus. Diabetes 41 [Suppl]: 184 A (Abstract) 
60. Freymond D, Bogardus C, Okubo M, Stone K, Mott D (1988) Impaired insulin-stimulated muscle glycogen synthase activation in vivo in man is related to low fasting glycogen synthase phosphatase activity. $J$ Clin Invest 82: 1503-1509

61. Thompson DB, Degregorio M, Sommercorn J (1992) Insulin resistance alters immediate early gene expression in human skeletal muscle in vivo. Diabetes 41 [Suppl]: $89 \mathrm{~A}$ (Abstract)

62. Damsbo P, Vaag A, Hother-Nielsen O, Beck-Nielsen H (1991) Reduced glycogen synthase activity in skeletal muscle from obese patients with and without type 2 (non-insulin-dependent) diabetes mellitus. Diabetologia 34:239-245

63. Gerich JE, Mitrakou A, Kelley D et al. (1990) Contribution of impaired muscle glucose clearance to reduced postabsorptive systemic glucose clearance in NIDDM. Diabetes 39: 211-216

64. Nyomba BL, Freymond D, Raz I, Stone K, Mott DM, Bogardus C (1990) Skeletal muscle glycogen synthase activity in subjects with non-insulin-dependent diabetes mellitus after glyburide therapy. Metabolism 39: 1204-1210

65. Cohen P (1983) Protein phosphorylation and the control of glycogen metabolism in skeletal muscle. Philos Trans R Soc Lond B Biol Sci 302: 13-25

66. Larner J (1983) Mediators of post-receptor action of insulin. Am J Med 17:38-51

67. Shulman GI, Rothman DL, Jue T, Stein P, DeFronzo RA, Shulman RG (1990) Quantification of muscle glycogen synthesis in normal subjects and subjects with non-insulin-dependent diabetes by ${ }^{13} \mathrm{C}$ nuclear magnetic resonance spectroscopy. $\mathrm{N}$ Engl J Med 322: 223-228

68. Bjøerbaek C, Vestergaard H, Heding LG, Cohen P, Pedersen O (1992) Analysis of genes encoding 3 key proteins in insulin resistant glucose utilization of skeletal muscle from type 2 diabetics. Diabetes 41 [Suppl 1]: 72 A (Abstract)

69. Groop L, Kankuri M, Nikula-Ijas P, Koivisto V (1992) Expression of the glycogen synthase gene in skeletal muscle of NIDDM patients and their first-degree relatives. Diabetes 41 [Suppl]: $68 \mathrm{~A}$ (Abstract)

70. Rothmann DL, Shulman RG, Shulman GI (1992) ${ }^{31} \mathrm{P}$ nuclear magnetic resonance measurements of muscle glucose 6-phosphate. J Clin Invest 89: 1069-1075

71. Bell GI, Kayano T, Buse JB et al. (1990) Molecular biology of mammalian glucose transporters. Diabetes Care 13: 198-208

72. Cushman SW, Wardzala LJ (1980) Potential mechanism of insulin action on glucose transport in the isolated rat adipose cell. $\mathrm{J}$ Biol Chem 255: 4758-4762
73. Obermaier-Kusser B, Mühlbacher Ch, Rattenhuber E et al. (1988) Further evidence for a two step model of glucose transport regulation. Biochem J 261: 699-705

74. Garvey WT, Huecksteadt TP, Matthei S, Olefsky JM (1988) Role of glucose transporters in the cellular insulin resistance of the type II non-insulin dependent diabetes mellitus. J Clin Invest 81: $1528-1536$

75. Handberg A, Vaag A, Damsbo P, Beck-Nielsen H, Vinten J (1990) Expression of insulin regulatable glucose transporters in skeletal muscle from type 2 (non-insulin-dependent) diabetic patients. Diabetologia 33: 625-627

76. Pedersen O, Bak JF, Andersen PH et al. (1990) Evidence against altered expression of GLUT 1 or GLUT 4 in skeletal muscle of patients with obesity or NIDDM. Diabetes 39:865-870

77. Friedman JE, Pories WJ, Legget-Frazier N et al. (1991) Evidence for decreased insulin sensitive glucose transporters (GLUT 4) in skeletal muscle from a large sample of obese and obese-NIDDM patients. Diabetes 40: A 158 (Abstract)

78. Vogt B, Mühlbacher C, Carrascosa J et al. (1992) Subcellular distribution of GLUT 4 in the skeletal muscle of lean type 2 (noninsulin-dependent) diabetic patients in the basal state. Diabetologia 35: 456-463

79. Friedman JE, Dohm GL, Leggett-Frazier N (1992) Restoration of insulin responsiveness in skeletal muscle of morbidly obese patients after weight loss. J Clin Invest 89: 701-705

80. Eriksson J, Koranyi L, Bourey R et al. (1992) Insulin resistance in type 2 (non-insulin-dependent) diabetic patients and their relatives is not associated with a defect in the expression of the insulin-responsive glucose transporter (GLUT-4) gene in human skeletal muscle. Diabetologia 35: 143-147

81. Choi WH, O'Rahilly S, Buse JB et al. (1991) Molecular scanning of insulin-responsive glucose transporter (GLUT 4) gene in NIDDM subjects. Diabetes 40: 1712-1718

82. Sun XJ, Rothenberg P, Kahn CR et al. (1991) Structure of the insulin receptor substrate IRS-1 defines a unique signal-transduction protein. Nature 352: 73

Dr. H.U.Häring

Institut für Diabetesforschung

Kölner Platz 1

W-8000 München 40

Germany 